\title{
ETIKA DAN PRINSIP PERBANKAN SYARIAH DALAM PERSFEKTIF HUKUM EKONOMI ISLAM
}

\author{
Saifullah Bombang \\ Dosen Istitut Agama Islam Negeri Palu \\ Email: saifullah bombang @gmail.co.id
}

\begin{abstract}
Abstrak
Etika, nilai yang bersumber dari ajaran Islam sumber utama dalam pembentukan prinsip-prinsip perbankan syariah dalam sistem hukum ekonomi Islam. Prinsip yang telah terekonstrumsi menjadi prinsip merupakan suatu kesatuan yang utuh dan tak terpisahkan satu kesatuan prinsip yang memiliki makna yang sama dan berlaku sepanjang masa. Keduanya saling mengikat tidak terpisahkan dan menjadi acuan dalam melaksanakan amal usaha (muamalah). Semua aktivitas dalam ekonomi Islam, termasuk perbankan selalu harus sesuai dengan prinsip-prinsip ajaran islam sehingga terhindar dari praktek perbankan yang penuh dengan pelanggaran terhadap nilai dan norma islam. Pemberlakuan prinsip-prinsip Islam dalam perbankan syariah yang dinormakan dalam hukum ekonomi islam dimaksudkan adalah untuk mengkonsistensikan ajaran Islam dengan praktek perbankan terkaontaminasi dengan sistem lain yang pada umumnya tidak sesuai dengan etika dan prinsip Islam. Islam menawarkan konsep kepada umat manusia yang bersumber dari al-Qur'an dan Sunnah dalam hal melakukan hubungan atau transaksi dengan orang lain, termasuk dalam bidang keuangan sebagai manisfestasi dari ajaran islam dalam bidang perbankan. Etika, Nilai dan prinsip menjadi acuan dan sumber dalam merumuskan norma hukum Islam yang mengatur hubungan hukum dalam bindang perbankan. Semuan transaksi keuangan dalam perbankan seharusnya tunduk pada norma hukum islam dan setiap muslim perlu berhati-hatian dan tidak terjebak dalam sistem transaksi perbankan yang tidak halal (riba dan subhat) sehingga eksistensi perbankan Islam semakin kokoh tumbuh dan kuat demi kemaslahatan umat manusia.
\end{abstract}

Kata Kunci: Etika, Prinsip Perbankan Syariah, Hukum Ekonomi Islam

\section{A. PENDAHUUAN}

Hukum Islam sebagai hukum positif (ius constitutum) di Indonesia bila dihubungkan dengan hukum Islam yang masih bersifat formal-yuridis, maka termasuk didalamnya hukum ekonomi Syariah / Ekonomi Islami, yang dalam tulisan ini membahas keterkaitan etika dan prinsip sebagai acuan hukum ekonomi Islam. Kedua hal tersebut terkait dengan sistem perbankan yang menjadi bagian kajian Fiqhi Muamalah / Hukum Perdata Islam. Isu tentang hukum ekonomi Islam dan lebih khusus pada perbankan syariah menjadi suatu fenomenal dalam masyarakat dari masa ke masa dan menjadi tuntutan masyarakat muslim yang ingin konsisten pada ajaran Islam.

Dalam dunia ekonomi dewasa ini, salah satu kegiatan ekonomi yang paling dominan dan sangat dibutuhkan keberadaannya adalah lembaga perbankan. Lembaga ini fungsinya sebagai penghimpun dana dan sangat menunjang perekonomian suatu bangsa. Sebagai alat penghimpun dana, lembaga keuangan tersebut menjadi lokomotif pembangunan dengan cara 
menyalurkan dana ke berbagai sektor produksi dan jasa, baik yang dikelola pemerintah maupun swasta. Permasalahan utama yang dihadapi pelaku usaha terhadap usaha perbankan dewasa ini yaitu berkaitan dengan ketentuan-ketentuan hukum Islam yang menghendaki agar setiap lembaga perbankan menerapkan sistem perbankan sesuai prinsip-prinsip syariah. Menurut Gemala Dewi bukanlah dari segi fungsi lembaga tersebut melainkan konsep dan teknik operasional usahanya serta jenis-jenis perjanjian yang dipergunakan ${ }^{1}$. Disadari bahwa kegiatan usaha yang digerakkan kelompok ekonomi kapitalis melalui perbankan konvensional dengan cara menarik keuntungan melalui bunga kredit menyebabkan sistem perbankan ini menjadi tumbuh dan dapat bertahan.

Konsep usaha dengan janji keuntungan yang berlipat ganda tanpa menanggung resiko rugi, tentu menimbulkan kontroversi dikalangan masyarakat muslim sehingga menimbulkan pertentangan dengan prinsip-prinsip hukum Islam yang menghargai usaha dan mengaharamkan riba. Sayyid Sabiq, dari beberapa hadis yang diungkap menunjukkan larangan dan haramnya memakan riba. Menurutnya, riba ada 2 macam, yaitu, pertama, riba nasi'ah yaitu pertambahan bersyarat yang diperoleh orang yang menghutangkan (kreditor) dari orang yang berhutang lantaran penangguhan (debitor). Jenis riba ini diharamkan berdasarkan al-Qur'an, As-Sunnah, Ijma' para imam. Kedua, riba fadhal yaitu jenis riba berupa jual beli uang dengan uang atau barang pangan dengan adanya tambahan. Hal ini sejalan dengan pendapat Adi Warman Karim dinamai riba karena mengandung pengertian tersebut. Selain itu, ada jenis ketiga riba yakni riba jahiliyyah. Jenis riba ini yaitu hutang yang dibayar melebihi pokok pinjaman, karena sipeminjam tidak mampu mengembalikan dana pinjaman pada waktu yang telah ditetapkan. Riba jahiliyyah pada hakekatnya tergolong riba nasi'ah jika dilihat dari segi penundaan waktu penyerahannya, tetapi dilihat dari kesamaan objek yang dipertukarkan maka tergolong riba fadhal.

Di Indonesia, ahli hukum Islam mengategorikan haramnya bunga bank ada 4 pendapat; Pertama, ada yang menganggap bunga bank halal dengan mengikuti paham bahwa yang diharamkan adalah bunga bagi hutang yang bersifat konsumtif saja ataupun yang menganggap bunga yang haram hanya yang berlaku pada zaman jahiliyyah sebelum Islam saja sedang bunga bank yang bersifat produktif dan dikelola secara profesional melalui lembaga atau badan hukum yang bukan perorangan. Kedua, menganggap bunga bank adalah haram akan tetapi dewasa ini umat Islam masih dapat menggunakan perbankan konvensional dengan alasan keadaan darurat. Ketiga, kelompok yang menegaskan bahwa bunga bank adalah haram dan semestinya ditinggalkan. Pendapat terakhir ini mengacu pendapat dari beberapa ulama besar, seperti, Abu Zahrah, guru besar pada fakultas hukum Universitas Kairo (Mesir), Abu A'la Al-Maudhudi (Pakistan), Muhammad Abdullah Al-A'rabi, Penasehat hukum pada Islamic Congres Kairo dan lain-lain yang menyatakan bahwa bunga bank itu adalah riba nasi'ah, yang dilarang oleh Islam ${ }^{2}$. Karena itu, umat Islam tidak boleh

\footnotetext{
${ }^{1}$ Lihat Gemala Dewi, Aspek Perbankan Perasuransian Syariah di Indonesia ( Cet.l; Jakarta: Kencana, 2004), h. 55

2 Riba dalam pandangan Agama Samawi (Islam, Yahudi dan Kristen) sepakat mengharamkannya. Dalam Agam Islam banyak sekali ayat-ayat Al-Qur'an maupun hadishadis Rasulullah SAW, mengharamkannya (Lihat, Surat Surat Al-Baqarah ayat 275, 276, 277, 278, 279, surat Al-Imran Ayat 130, surat An-Nisa ayat 161, surat Ar-Rum ayat 139 ). Demikian pula hadis-hadis Rasulullah SAW. Ijma' ulama yang kesemuanya itu dapat dilihat dalam pembahasan disertasi berikutnya. Mengenai pandangan agama-agama samawi (yahudi dan Kristen) mengenai riba dapat dilihat berikut ini. Orang-orang Yahudi dilarang
} 
bermuamalah dengan bank yang memakai sistem bunga, kecuali dalam keadaan darurat atau terpaksa. Mereka mengharapkan perbankan Islam yang tidak memakai sistem bunga sama sekali. Keempat, pendapat dari majelis Tarjih Muhammadiyah menyatakan adanya sifat "Syubhat" atau "Musytabihat". Artinya, belum jelas haram / halalnya sehingga kedepan (ius constituendum) diperlukan ketegasan dalam bentuk peraturan perundang-undangan bahwa riba adalah haram hukumnya dalam sistem perbankan dan hal ini menjadi tugas dan tanggung jawab pemegang otoritas hukum di Indonesia. Pernyataan ini telah pernah dikemukakan oleh beberapa ahli hukum Islam jauh sebelum bank Syariah pertama berdiri di Indonesia.

Dewasa ini, setelah jumlah bank-bank Syariah sudah cukup banyak, Majelis Ulama Indonesia (MUI) dalam Rakernasnya pada tanggal 16 Desember 2003 sependapat dengan pendapat ketiga di atas dan telah memutuskan bahwa "bunga bank hukumnya haram". Fatwa ini telah ditetapkan pada tanggal 6 Januari 2004 yang pada dasarnya tidak perlu menimbulkan perdebatan sekiranya ummat Islam istiqamah (konsisten) memegang Syariah Islam sehingga sistem perbankan yang menerapkan sistem bunga bank bagaimanapun bentuknya hukumnya tetap haram dan bahkan agama-agama lainpun mengharamkannya. Realitas tersebut memberi ruang kepada hukum perbankan syariah untuk tumbuh sebagai sistem perbankan yang diharapkan dapat menjadi rujukan dalam sistem perbankan di Indonesia yang dapat memberikan keadilan dan kemanfaatan bagi kemaslahatan umat manusia.

\section{B. Metode}

Metode yang digunakan dalam penelitian ini adalah menggunakan metode penelitian normative dengan model penalaran hukum deduktif-induktif terhdap isu hukum tentang sistem perbankan syariah yang berbasis pada prinsip-prinsip Islam yang bersumber dari Al-Qur'an dan Sunnah Rasulullah Saw. Model argumentasi hukum yang berorientasi pada penalaran tersebut sepenuhnya bertumpu pada nilainilai dan prinsip-prinsip Islam dalam merekonstruksi prinsip-prinsip perbankan syari'ah yang dapat diberlakukan dalam sistem perbankan Syari'ah di Indonesia.

\section{Penelusuran Teori}

Dalam penulisan ini, teori yang menjadi acuan bersumber dari beberapa teori yang relevan mendukung argumentasi hukum eksistensi perbankan syari'ah. Beberapa teori dimaksud antara laian, teori fiqhi muamalah yang dikemukakan oleh Abdul Wahab Khalaf. Teori menyatakan bahwa fiqhi muamalah adalah mengatur hubungan manusia dengan sesamanya baik dari segi hukum, ketertiban, dan keadilan secara perorangan

mempraktekkan pengambilan riba sebagaimana tercantum dalam kitab Oldstestament (Perjanjian Lama) maupun undang-undang Talmut. Jika engkau meminjamkan uang kepada salah seorang dari umatku orang yang miskin diantaramu dan janganlah engkau berlaku sebagai penagih hutang terhadap dia. Janganlah engkau bebankan bunga uang terhadapnya (Kitab Exodus Keluarga) pasal 22 ayat 25 ) dapat juga dilihat (Kitab Dubteronkomy (Ulangan) Pasal 23 ayat 19. Kitab levicitus (Imamat) pasal 25 ayat 36-37. Dalam Agama Kristen dinyatakan dalam kitabnya "Jangan engkau memberinya uang dengan riba, dan jangan juga meminjaminya makanan-makanan untuk mendapatkan tambahan (Lebitikus pasal 25 ayat 35-37), lihat pula hubungannya dengan Lukas Pasal 6 ayat 34-35, Lukman Pasal 6 ayat 35, Eksodus Pasal 22 ayat 25, ulangan pasal 23 ayat 19-20.

3 Lihat Putusan Majelis Tarjih Muhammadiyah 
maupun permasyarakatan, antara lain hukum kekeluargaan, hukum sipil, hukum pidana, hukum ketatanegaraan, hukum internasional dan hukum ekonomi (mengatuk hak-hak seorang pekerja dan orang yang memperkerjakannya serta mengatur sumber keuangan Negara dan penditribusiannya bagi kepentingan dan kesejahteraan rakyat ${ }^{4}$. Selain itu, teori etika Islam yang dikemukakan oleh Yusuf Qardlawi yang secara tegas membedakan hukum dan etika Islam dengan materialisme sehingga ekonomi Islam memiliki kompetensi dasar. Adapun Kompetensi Dasar Ekonomi Islam, yaitu. (1) Kompetensi untuk kesadaran etika (etnichal sensibility) (2) Kompetensi untuk berpikir secara logika (etnichal reasoning), (3) Kompetensi untuk bertindak secara etika (etnichal conduct) dan (4)Kompetensi untuk kepemimpinan etika (etnichal leadership) ${ }^{5}$.

\section{PEMBAHASAN}

\section{Etika Dalam Hukum Ekonomi Islam}

Hukum ekonomi Islam adalah himpunan peraturan hukum yang diambil dari wahyu dan diformulasikan dalam keempat produk pemikiran hukum fiqh, fatwa, keputusan pengadilan, dan undang-undang yang dipedomani dan diberlakukan bagi umat Islam di Indonesia $^{6}$. Pemahaman terhadap hukum islam tersebut telah menjadi bagian dari hukum islam yang dianut dalam yurisprudensi hukum islam dalam masyarakat muslim. Dalam kaitan membahas masalah perbankan syariah tidak lepas dari rangkaian fiqhi muamalah yang menurut Abdul Wahab Khalaf bahwa fiqhi muamalah adalah mengatur hubungan manusia dengan sesamanya baik dari segi hukum, ketertiban, dan keadilan secara perorangan maupun permasyarakatan, antara lain hukum kekeluargaan, hukum sipil, hukum pidana, hukum ketatanegaraan, hukum internasional dan hukum ekonomi (mengatuk hak-hak seorang pekerja dan orang yang memperkerjakannya serta mengatur sumber keuangan Negara dan penditribusiannya bagi kepentingan dan kesejahteraan rakyat ${ }^{7}$.

Etika dan hukum dalam ekonomi Islam dapat dikatakan satu kesatuan yang tak terpisahkan, sebab manusia dibekali dengan norma aturan dan nilai baik yang berasal dari Tuhan maupun hasil pemikiran manusia yang dapat menjadi acuan untuk bertindak dan memilih perilaku yang baik atau buruk, benar atau salah, diperbolehkan atau dilarang dan lain sebagainya. Etika sebagai ilmu pengetahuan merupakan cabang filsafat tentang tingkahlaku manusia yang fokus utamanya yaitu menentuan perilaku baik dan buruk. Sebagai ilmu pengetahuan tentang asas-asas akhlak atau kumpulan asas atau nilai yang berkenaan dengan akhlak, maka etika mempersoalkan atau mengakaji moralitas dan nilai tindakan moral yang dalam penerapannya menurut sistem syariah dan etika islam yang dianut dalam ajaran Islam.

Dalam beberapa literatur, istilah etika dan moral sering dipakai untuk makna yang sama, namun, dilihat dari asal kata dan sumber terdapat perbedaan sebab etika berasal dari bahasa Yunani yaitu "ethos" yang memiliki arti adat, akhlak, watak, perasaan, sikap dan cara berpikir atau berarti adat istiadat dan moral berasal dari kata "morales" sebuah kata latin

4 Lihat Abdul Wahab Khalaf, 'Ilm Usul al-Fiqh, Jakarta: Maktabah al-Da'wah al-Islamiyah Syabab al-Azhar, 1410/1990, cet. 8, hlm. 96.

${ }^{5}$ Lihat Sony Keraf, Etika Bisnis : Membangun Citra Bisnis Sebagai Profesi Luhur (Yogyakarta : 1991), h. 77

${ }^{6}$ Lihat Departemen Pendidikan dan Kebudayaan, op. cit.,,h. 1104.

7 Lihat Abdul Wahab Khalaf, 'Ilm Usul al-Fiqh, Jakarta: Maktabah al-Da'wah al-Islamiyah Syabab al-Azhar, 1410/1990, cet. 8, hlm. 96. 
yang seringkali diasumsikan dengan etika ${ }^{8}$. Kedua kata tersebut, yaitu moral dan etika dapat dihomogenkan seperti "custom or mores". Moral tidak bersumber pada individu, melainkan bersumber dari masyarakat dan merupakan gejala masyarakat. Moral masyarakat berkuasa terhadap individu, dalam arti kewajiban, misalnya yang berbicara adalah suara masyarakat, sehingga masyarakatlah yang menentukan dan menekankan segala peraturan kehidupan itu berlaku. Sementara, etika dapat berasal dari hasil pemikiran seseorang yang kemudian diikuti oleh suatu komunitas tertentu. Sungguhpun demikian, nilai-nilai moral yang bersifat filosof itu, pada satu sisi oleh sebagian ilmuan, seperti pandangan Lewis Molford Adams ${ }^{10}$ bahwa nilai-nilai moral menjadi titik fokus etika dan dalam hal ini ide tentang perilaku manusia terkadang menisbikan fakta yang berwujud tingkah laku manusia, sehingga semua tindakan manusia dalam masyarakat senantiasa dikontrol oleh masyarakat. Selain itu, rumusan etika dapat bersumber dari masyarakat yang diperoleh secara kontemplatif meskipun tidak didukung realita faktual di lapangan.

Selanjutnya, jika dilihat dari ajarannya, Islam tidak memisahkan antara ekonomi dengan nilai-nilai etika dan hukum, sebagaimana tidak memisahkan dunia ilmu dengan akhlak, dunia politik dengan etika, perang dengan etika dan kerabat sedarah dalam tatanan kehidupan masyarakat Islam. Singkatnya, hukum dan etika dalam Islam merupakan suatu keniscayaan. Pandangan ini dikemukakan oleh Yusuf Qardlawi yang juga secara tegas membedakan hukum dan etika Islam dengan materialisme sehingga ekonomi Islam memiliki kompetensi dasar. Adapun Kompetensi Dasar Ekonomi Islam, yaitu. (1) Kompetensi untuk kesadaran etika (etnichal sensibility) (2) Kompetensi untuk berpikir secara logika (etnichal reasoning), (3) Kompetensi untuk bertindak secara etika (etnichal conduct) dan (4)Kompetensi untuk kepemimpinan etika (etnichal leadership $)^{l 1}$. Keempat kompetensi dasar ekonomi Islam tersebut menjadi dasar pertimbangan dan argumentasi serta perumusan prinsip-prinsip dan norma-norma hukum ekonomi Islam.

\section{Prinsip Kebebasan Dalam Hukum Ekonomi Islam}

Pemberlakuan prinsip-prinsip dan kebebasan dalam hukum ekonomi islam bersandar pada etika ekonomi yang bersumber dari prinsip-prinsip etika pada umumnya. Selain itu, dalam ekonomi Islam etika dalam ekonomi menjadi pegangan dalam kegiatan ekonomi dan berjalan sesuai prinsip-prinsip, kodrat dan aturan hukum yang ada. Prinsip-prinsip itu, antara lain, prinsip otonomi. Prinsip ini adalah prinsip dan kemampuan manusia untuk bertindak berdasarkan kesadarannya sendiri tentang apa yang dianggapnya baik untuk dilakukan. Untuk bertindak secara otonom, semestinya ada kebebasan untuk mengambil keputusan dan bertindak berdasarkan keputusan itu disertai dengan tanggung jawab. Kondisi ini disebabkan karena manusia diberi kemampuan yang dalam terminologi fiqh disebut al-

${ }^{8}$ Lihat M. Dawan Rahardjo, Etika Ekonomi dan Manejemen (Yogyakarta : Tiara Wacana Yogya, 1990), h.3

${ }^{9}$ Ibid.

${ }^{10}$ Dikutip Lihat Lewis Mulford Adam mendefinisikan etika dengan : Etnich is the of moral philosophy concerned not with the fact, but with values; not with the character of, but the ideal of the product. Lihat dalam Asmaran, Pengantar, h.6

11 Lihat Sony Keraf, Etika Bisnis : Membangun Citra Bisnis Sebagai Profesi Luhur (Yogyakarta : 1991), h. 77 
ahliyah baik dalam kapasitas ahliyah al-wujub maupun ahliyah al-ada ${ }^{, 12}$. Kemampuan yang sempurna memberikan tanggung jawab penuh pada pelaksanaan setiap aktivitas ekonomi. Kemampuan itu baru berfungsi secara maksimal jika sikap otonom dimiliki. Dalam kaitannya dengan sikap otonomi, sikap tanggung jawab penting karena, (a) Kesediaan untuk melakuakn apa yang harus dilakukan, dengan sebaik mungkin, Bertanggungjawab berarti sikap seseorang terhadap tugas yang membebani instansi atau dirinya. Ia merasa terikat untuk menyelesaikannya, demi tugas itu sendiri (b) Sikap bertanggungjawab lebih tinggi daripada tuntutan etika atau peraturan. Etika atau peraturan hanya mempertanyakan apakah sesuatu boleh atau tidak, sedangkan sikap bertanggungjawab lebih terikat dengan nilai yang diemban atau yang dihasilkan (c) wawasan orang yang bersedia untuk bertanggungjawab secara prinsip tidak terbatas, Ia tidak membatasi perhatiannya pada apa yang menjadi urusan dan kewaijbannya, melainkan merasa bertanggungjawab di mana saja diperlukan (d) Kesediaan bertanggungjawab termasuk kesediaan untuk diminta dan untuk memberi pertanggungjawaban atas tindakan-tindakannya ${ }^{13}$. Pelaksanaan tugas dan kewajiban dalam ekonomi islam secara bebas dan otonom meliputi : (1) kebebasan dalam bertransaksi (2) kebebasan dalam berproduksi (3) kebebasan dalam berbelanja, memiliki dan mengonsumsi (4) kebebasan dalam memilih, melanjutkan atau membatalkan transaksi dan (5) kebebasan dalam menentukan harga dan barang ${ }^{14}$. Jadi, kebebasan dalam ekonomi Islam dimaksudkan pada kebebasan eksistensial, yaitu keleluasaan dalam melakukan aktivitas ekonomi tanpa ada paksaan dari orang yang mengkibatkan aktivitas itu tidak sesuai dengan kehendak pelakunya. Kebebasan dalam ekonomi Islam bersangkut paut dengan kebebasan jasmani dan rohani. Seorang muslim dapat melakukan transaksi ekonomi secara fisik dan sekaligus ia bebas menentukan sendiri apakah menyukai suatu jenis transaksi atau tidak. Dengan kata lain, Kebebasan dalam ekonomi Islam terwujud dalam bentuk fisik berupa kebebasan untuk mengadakan aktivitas ekonomi dan kebebasan untuk menyukai atau menolak kegiatan ekonomi tertentu.

Kebebasan sosial juga terdapat dalam ekonomi Islam ketika seseorang dilarang memaksa orang lain untuk melakukan atau meninggalkan transaksi ekonomi tertentu, pemaksaan agar orang lain menghindari sebuah aktivitas ekonomi berarti perampasan kebebasan secara sosial. Islam melarang perbuatan semacam ini kecuali orang tertentu atau tidak cakap dalam melakukan transaksi ekonomi seperti anak dibawah umur, orang gila dan atau orang dibawa pengampuan.

Dalam ekonomi Islam, kebebasan merupakan hal esensial karena sah atau tidaknya suatu akad terletak pada kebebasan untuk meneruskan atau tidak aktivitas ekonomi tersebut. Dalam al-Qur'an kebebasan itu disebut dengan ridha, rela atau suka sama suka. Kerelaan menjadi kunci pokok kesahan sebuah transaksi dan ketidakrelaan yang digambarkan dengan kebatilan dalam al-Qur'an juga merupakan kunci pokok ketidaksahan suatu transaksi ekonomi. Dalam Q.S. al-Nisa'/29 dinyatakan :

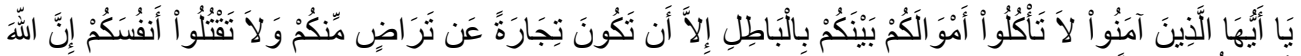

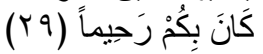

\footnotetext{
${ }^{12}$ Lihat Alois A. Nugroho, Dari Etika Bisnis ke Etika Ekobisnis (Jakarta : Grasindo, 2001 M.),
} h. $27-28$

${ }^{13}$ Ibid., h. 26-27

14 Ibid. 
Terjemahnya :

"Hai orang-orang yang beriman, janganlah kamu saling memakan harta sesamamu dengan jalan yang batil, kecuali dengan jalan perniagaan yang berlaku dengan suka sama-suka di antara kamu, Dan janganlah kamu membunuh dirimu; Sesungguhnya Allah adalah maha penyayang kepadamu."15

Ayat di atas menunjukkan bahwa seseorang yang dengan suka rela memberikan kepada dan/atau menerima dari orang suatu benda diperbolehkan mengambil manfaat darinya, Sebaliknya, tanpa kerelaan misalnya dengan cara mencuri, menipu, memeras dan sebagainya, maka orang itu dinyatakan memperoleh benda secara batil dan karenanya ia tidak diperbolehkan mengambil manfaat dari benda tersebut. Dalam kerelaan di atas terdapat kebebasan untuk bertransaksi karena tidak ada pihak yang dirugikan dan sebaliknya pada kebatilan tidak terdapat kebebasan karena di samping mengandung kerugian juga merampas hak orang lain.

\section{Prinsip Kesamaan Makna Dalam Hukum Ekonomi Islam}

Kata bank dari kata banque dalam bahasa Prancis, dan dari banco dalam bahasa Italia, yang berarti peti/lemari atau bangku ${ }^{16}$. Kata peti atau lemari menyiratkan fungsi sebagai tempat menyimpan benda-benda berharga, seperti peti emas, peti berlian, peti uang dan sebagainya. Dalam al-Qur'an, istilah bank tidak disebutkan secara eksplisit, akan tetapi jika yang dimaksud adalah sesuatu yang memiliki unsur-unsur seperti struktur, manajemen, fungsi, hak dan kewajiban dapat diketahui melalui beberapa istilah, seperti zakat, sadaqah ghanimah (rampasan perang), bai' (jual beli), dayn (utang dagang), maal (harta) dan sebagainya, yang memiliki fungsi dan peran tertentu dalam kegiatan ekonomi ${ }^{17}$. Karena itu, dalam penerapannya beberapa istilah tersebut pada umumnya diterapkan pada perbankan syariah adalah lembaga keuangan yang usaha pokoknya memberikan kredit dan jasa-jasa lain dalam lalu lintas pembayaran serta peredaran uang yang beroperasi disesuaikan dengan prinsip-prinsip syari'ah. Dalam kaitan itu, prinsip yang berlaku dalam perbankan syariah merujuk pada sifat dan fungsionalisasi lembaga-lembaga yang disebut secara tegas dalam ajaran Islam (al-Quran dan Sunnah) yang tugas dan maknanya sama dalam penerapannya dalam perbanan islam.

Fungsionalisasi makna-makna dari lembaga syariah tersebut (zakat, sadaqah, ghanimah) menjadi acuan dalam perumusan etika, nilai dan norma hukum dalam hukum ekonomi islam. Oleh karena itu, semua usaha bank yang selalu berkaitan dengan masalah keuangan sebagai dagangan utamanya, pemaknaannya harus tunduk pada etika, nilai dan norma hukum islam. Pemaknaan tersebut menjadikan semua kegiatan dan usaha bank yang selalu berkaitan dengan komoditas yang aktivitasnya antara lain, (a) Pemindahan uang (b) Menerima dan membayaran kembali uang dalam rekening koran (c) mendiskonkan surat wesel, surat order maupun surat-surat berharga lainnya (d) membeli dan menjual surat-surat berharga (e) Membeli dan menjual cek wesel, surat wesel, kertas dagang (f) Membeli kredit, dan (g) Memberi jaminan kredit ${ }^{18}$, selalu berorientasi pada etika, nilai dan norma hukum

${ }^{15}$ Lihat, Departemen Agama RI, Al-Qur`an dan Terjemahannya. Semarang, C.V . AlWaah, 1995, hlm. 83

${ }^{16}$ Lihat Zainul Arifin, (2002), Dasar-Dasar Manajemen Bank Syariah, Alvabet, Jakarta, h.2.

${ }^{17}$ Zainul Arifin, (2002), Ibid, h. 3.

${ }^{18}$ Tim Redaksi, (1994), Ensiklopedi Hukum Islam, PT. Ichtiar Baru, Van Hoeve, Jakarta. h. 194. 
islam. Itulah sebabnya semua jenis transaksi perbankan tersebut juga diterapkan pada semua lembaga perbankan dan menjadi produk serta jasa lembaga perbankan, termasuk dalam perbankan syariah seharusnya tunduk pada etika, nilai dan norma hukum islam yang bersumber dari ajaran islam.

Dalam catatan sejarah, gagasan untuk mendiri u cita-cita hukum masyarakat muslim dengan menggunakan prinsip-prinsip syariah. kan bank syariah di Indonesia sebenarnya sudah muncul sejak pertengahan tahun 1970-an. Hal ini dibicarakan pada seminar nasional Hubungan Indonesia-Timur Tengah pada 1974 dan pada tahun 1976 dalam seminar internasional yang diselenggarakan oleh lembaga Studi Ilmu-Ilmu Kemasyarakatan (LSIK) dan Yayasan Bhineka Tunggal Ika. Namun, ada beberapa alasan yang menghambat terealisasinya idea tau gagasan tersebut, yakni:

1) Operasi bank syariah yang menerapkan prinsip bagi hasil belum diatur, dan Karena itu, tidak sejalan dengan UU Pokok Perbankan yang berlaku, yakni UU No. 14/1967.

2) Konsep bank syariah dari segi politis berkonotasi ideologis, merupakan bagian dari atau berkaitan dengan konsep Negara Islam, dank arena itu tidak dikehendaki pemerintah.

3) Masih dipertanyakan, siapa yang bersedia menaruh modal dalam ventura semacam itu; sementara pendirian bank baru dari Timur Tengah masih dicegah, antara lain pembatasan bank asing yang ingin membuka kantornya di Indonesia ${ }^{19}$.

Dalam perfsfektif sejarah, gagasan mengenai bank syariah itu muncul lagi sejak tahun 1988, di saat pemerintah mengeluarkan Paket Kebijakan Oktober (Pakto) yang berisi liberalisasi industri perbankan. Para ulama pada waktu itu berusaha untuk mendirikan bank bebas bunga, tapi tidak ada satupun perangkat hukum yang dapat dirujuk, kecuali bahwa perbankan dapat saja menetapkan bunga sebesar 0\%. Setelah adanya rekomendasi dari lokakarya ulama tentang bunga bank dan perbankan di Cisarua, Bogor tanggal 19-22 Agustus 1990, yang kemudian dibahas lebih mendalam pada Musyawarah Nasional (Munas) IV Majelis Ulama Indonesia (MUI) yang berlangsung di Hotel Sahid Jaya, Jakarta, 22-25 Agustus 1990, dibentuklah kelompok kerja untuk mendirikan bank syariah di Indonesia ${ }^{20}$. Dari segi kelembagaan dan ketentuan perundang-undangan, perbankan Syariah meliputi kegiatan usaha serta cara dan proses dalam melaksanakan kegiatan usahanya sesuai dengan Pasal 1 angka 1 UU No 21 Tahun 2008 Tentang Perbankan Syariah. Sedangkan Bank Syariah adalah "Bank yang menjalankan kegiatan usahanya berdasarkan prinsip syariah dan menurut jenisnya terdiri atas Bank Umum Syariah dan Bank Pembiayaan Rakyat Syariah" (Pasal 1 angka 7 UU Perbankan Syariah. Kartena itu, jika disebut Perbankan Syari'ah, maka ia merujuk pada Bank Umum Syariah (BUS), Unit Usaha Syari'ah (UUS), dan Bank Pembiayaan Rakyat Syariah (BPRS). Sedangkan jika disebut Bank Syariah, maka hanya merujuk pada BUS dan BPRS. Jika disebut BUS atau UUS, atau BPRS, maka hanya merujuk pada istilah yang disebut tadi.

Dalam perundang-undangan Perbankan Syariah, ketentuan yang diperuntukkan untuk Perbankan Syariah disebut dengan terminologi "Perbankan Syarih" atau "Bank Syariah dan Undang Undang Ssyariah". Terminologi ini memiliki makna yang meliputi semua kegiatan yang berkaitan dengan perbankan. Berkaitan dengan kelembagaan, Undang-Undang

${ }^{19}$ Lihat Muh Dawam Rahardjo, (1999) Islam dan Transformasi Sosial-Ekonomi, Lembaga Studi Agama dan Filsafat, Jakarta, h. 405

${ }^{20}$ Ibid, h. 406 
Perbankan Syariah menentukan bahwa Bank Konvensional yang melaksanakan layanan Syariah, harus terlebih dahulu membuka Undang Undang Syariah (Pasal 5 ayat 9 UU Perbankan Syariah). Selanjutnya, UU Perbankan Syariah mendorong agar UUS menjadi BUS. Untuk itu, UU Perbankan Syariah menekan bahwa "dalam hal Bank Umum Konvensional memiliki UUS yang nilai asetnya telah mencapai paling sedikit 50 persen (lima puluh perseratus) dari total nilai asset bank induknya atau 15 (lima belas) tahun sejak berlakunya UU ini, maka berdasarkan ketentuan tersebut, Bank Umum Konvensional dimaksud melakukan pemisahan Undang Undang Syariah tersebut menjadi Bank Umum Syariah" (Pasal 68 UU Perbankan Syariah). Disamping itu, UU Perbankan Syariah menetapkan pula bahwa Bank Umum Syariah, undang-Undang Syariah atau BPRS tidak boleh dialihkan menjadi Bank Umum Konvensional atau BPR (Pasal 5 ayat 7 dan 8 UU Perbankan Syariah).

Berdasarkan beberapa ketentuan perundang-undang tersebut, maka seharusnya semua perbankan yang aktivitasnya dalam kegiatan ekonomi tunduk pada prinsip kesamaan makna dengan nilai dan norma-norma hukum Islam. Prinsip ini menjadikan semua aktivitas perbankan Islam menjadi penciri atau pembeda dengan perbankan lain. Prinsip ini juga menjadi daya tarik tersendiri dan pembebas dari sistem lain yang dapat menjerumuskan pihak perbankan dan nasabah terjerumus dalam praktek perbankan tidak islami.

\section{Prinsip Bebas Riba (Bunga) Dalam Hukum Ekonomi Islam}

Riba berasal dari bahasa Arab, secara bahasa bermakna "al-ziyada yang berarti "tambahan". Dalam pengertian bahasa, riba juga berarti "tumbuh " dan " membesar "21. Para ulama berbeda pendapat dalam definisikan riba. Perbedaan itu disebabkan mereka memahami dan menginterpretasikan nash al-Quran dan Sunnah Rasul. Al-Jurjani, misalnya merumuskan bahwa "Riba secara Syar'i adalah kelebihan atau tambahan pembayaran tanpa ada ganti atau imbalan, yang disyaratkan bagi salah seorang dari dua orang yang membuat akad atau transaksi ".22. Dalam hal itu, maka Riba hal yang diharamkan dalam syariat Islam. Keharaman riba disebut secara tegas dalam al-Quran.

Dalam al-Quran, istilah riba disebut sebanyak tujuh kali. Dari tujuh ayat tersebut, proses keharaman riba, sebagaimana yang terjadi pada khamr, berlangsung dalam empat tahap. Keharaman riba tidak langsung satu kali, tetapi berlangsung secara bertahap, terkait dengan kondisi dan kesiapan masyarakat dalam menerima suatu perintah. Tahap pertama adalah Surat al-Rum (30): 39, ayat yang menerangkan tentang asumsi manusia yang menganggap harta riba akan menambah hartanya, padahal di sisi Allah Swt. Asumsi itu sebenarnya tidak benar, karena hartanya tidak bertambah karena melakukan riba. Allah swt. berfirman:

${ }^{21}$ Lihat Abbdullah Saeed, Islamic Banking and Interest A Study Of Prohibition Of Riba and its Contemporary Interpretatio, (Leiden EJ. Brill, 1996) h .2

22 Lihat Ali bin Muhammad al-Syarif al-Jurjani, Kitab, al- Ta'rifat (Beirut: Maktabah Libnan, 1990), h. 114; Al-Raghib al-Asfahani, Mufradat fi Gharib al-Qur'an, (Mesir: Musthafa al-Babi al-Halabi wa Auladuh, t.th.), h. 187. 


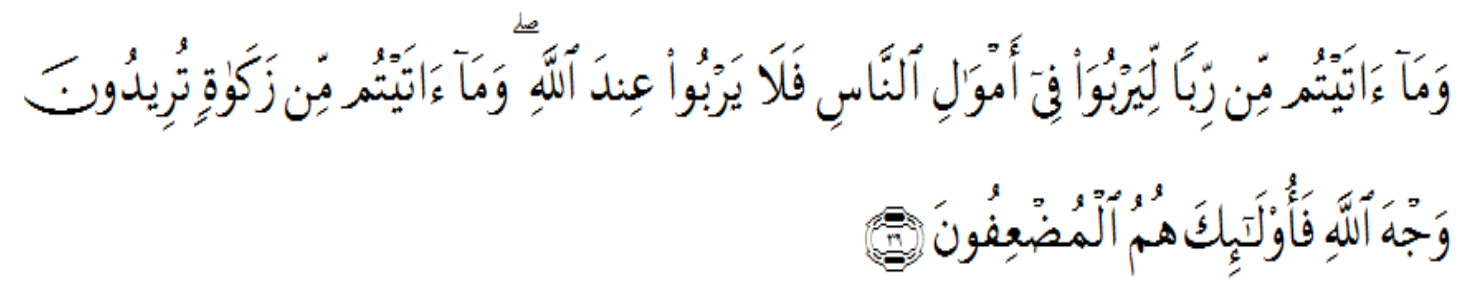

Terjemahnya:

"Dan sesuatu riba (tambahan) yang kamu berikan agar dia bertambah pada harta manusia, maka riba itu tidak menambah pada sisi Allah. Dan apa yang kamu berikan berupa zakat yang kamu maksudkan untuk mencapai keridhaan Allah, maka (yang berbuat demikian)"'23.

Dari ayat tersebut diketahui bahwa riba merupakan hal yang diharamkan, meskipun demikian terdapat beberapa pandangan ahli hukum Islam tentang Bunga Bank mengakaterikan sebagai riba yaitu, pertama, pandangan yang menyatakan bunga bank adalah termasuk riba sehingga hukumnya haram, sedikit atau banyak unsur, kedua, pandangan yang mengatakan bahwa bunga bank bukan termasuk dalam kategori riba sehingga la halal untuk dilakukan, dan Ketiga pandangan yang mengambil jalan tengah pada kedua pandangan di atas, mereka mengkategorikan riba dalam klasifikasi hukum mutasyahihat, sesuatu yang samar ketegasan hukumnya. Olehnya itu, mereka berpendapat sebaiknya bunga bank tidak dipraktekkan dalam lembaga perbankan syariah. Salah seorang yang berpendapat bahwa bunga bank itu dibolehkan karena tidak sama dengan riba yaitu Syafruddin Prawiranegara. Menurutnya, bahwa riba atau yang ia sebut dengan woeker, berbeda dengan bunga bank. Bunga bank adalah rente, yaitu tingkat bunga yang wajar, hanya boleh dipungut berdasarkan undang-undang, tidak dipungut secara liar tanpa adanya aturan vang mengatur keberadaannya. Sedangkan riba menurutnya adalah tiap-tiap laba yang abnormal yang diperoleh dalam jual beli bebas, tetapi di mana satu pihak terpaksa menerima kontrak jual beli itu karena kedudukannya lemah. Bunga bank yang dilakukan dengan tidak berdasarkan pada prinsip ekspoloitasi bukan merupakan riba. Menurut Syafruddin Prawiranegara, baik laba maupun bunga, apakah tetap atau naik turun, jika didasarkan pada persetujuan yang bersih dan ikhlas adalah sah dalam pandangan Allah swt. Sebaliknya laba yang berlebihan, termasuk bunga yang berasal dari perdagangan barang atau uang yang tidak jujur, adalah riba, sebab perbuatan itu merupakan pelanggaran terhadap ketentuan Allah swt., manusia harus berbuat baik dan tidak menipu serta menekan hambanya ${ }^{24}$. Bagi A.M. Saefuddin, bunga identik dengan riba, olehnya itu perbuatan membungakan uang adalah haram hukumnya, baik sedikit maupun banyak tingkat bunganya. Menurutnya, "Bunga pinjaman uang, modal dan barang dengan segala bentuk dan macamnya, baik untuk tujuan produktif atau konsumtif,

${ }^{23}$ Lihat Departemen Agama RI. Op.cit. h. 408

${ }^{24}$ Lihat pandangan Syafruddin Prawiranegara, Ekonomi dan Keuangan: Makna Ekonomi Islam (Kumpulan Karangan Terpilih Jilid II), (Jakarta: CV Masaagung, 1988), h. 347. 
dengan tingkat bunga yang tinggi atau rendah, dan dalam jangka waktu yang panjang maupun pendek adalah termasuk riba"25.

Selanjutnya, pandangan tentang bunga uang sebagai riba, juga dikemukakan oleh ulama lainnya, didasarkan pada ayat tentang keharaman riba yang ada dalam al-Quran seperti Surat al-Baqarah (2): 275-280, Ali 'Imran (3): 130; 30: 39, dan tentu saja diperkuat lagi dengan hadis Nabi. Secara aqli menurut A.M. Saefuddin, hakekat pelarangan riba (bunga bank) dalam Islam adalah fenomena penolakan terhadap resiko finansial tambahan yang ditetapkan dalam transaksi uang atau modal maupun jual-beli yang dibebankan kepada salah satu pihak (debitur) saja sedangkan pada pihak yang lain (kreditur) dijamin keuntungannnya ${ }^{26}$. Tampaknya aspek keadilan tidak mendapat perhatian dan pertimbangan dalam transaksi semacam ini. Dalam kaitan itu, Muhammadiyah berpendapat bahwa hukum bunga bank dari bank-bank milik pemerintah hukumnya syubhat, sedangkan bunga bank dari bank-bank milik swasta diharamkan ${ }^{27}$. Keputusan ini diambil ketika sidang Majelis Tarjih di Sidoarjo tahun 1969, memutuskan sebagai berikut: (1). Riba hukumnya haram dengan nash sharih Alquran dan sunnah. 2. Bank dengan sistem riba hukumnya haram dan bank tanpa riba hukumnya halal. Bunga yang diberikan oleh bank-bank milik negara kepada para nasabahnya atau sebaliknya yang selama ini berlaku, termasuk perkara mutasyabihat ${ }^{28}$.

Dalam catatan sejarah, praktek bunga dalam dunia perdagangan dan investasi di negara-negara Islam mulai muncul pada abad ke-19 yang diperkenalkan dan dipraktekkan oleh negara-negara Barat ketika mereka menjajah negara-negara Islam. Padahal menurut Siddiqi, sebelum terjadinya imperialisme di negara-negara Islam, masyarakat muslim pada abad ke-13 M yang merupakan super power baik dalam bidang militer dan ekonomi pada saat itu, melakukan kegiatan perekonomian mereka dalam skala domestik maupun internasional tidak mengenal adanya bunga (interest) ${ }^{29}$. Mereka melakukan investasi seperti dalam industri-industri tekstil dan sebagainya menggunakan sistim bagi hasil (profit sharring). Praktek ini berlangsung sampai negara-negara Barat memperkenalkan sistim bunga (interest $)^{30}$. Pada abad ke 20, munguat kesadaran dikalangan umat Islam untuk melepaskan diri dari imperialisme Barat, membawa dampak yang cukup luas dalam kehidupan sosial politik dan ekonomi mereka. Dalam dunia ekonomi mereka ingin melepaskan diri dari konsep ekonomi yang berasal dari negara-negara Barat yang tidak sesuai dengan nilai-nilai Islam, antara lain bunga bank. Oleh karena itu, dipandang perlu adanya sebuah bank Islam yang bebas dari praktek bunga. Ide pendirian bank Islam di Indonesia tidak terlepas dari adanya wacana yang begitu intens tentang pendirian bank-bank Islam di Negara-negara Islam yang menurut Dawam Rahardjo, munculnya gagasan pembentukan

25 Lihat Penjelasan mendetail tentang nilai instrumental, nilai dasar, dan filsafat yang merupakan komponen dari sistem ekonomi Islam dalam pandangan A.M. Saefuddin; lihat A.M Saefuddin, Ekonomi dan Masyarakat dalam Perspetif Islam, (Jakarta: Rajawali Press, 1987), h. 53-83

${ }^{26}$ Ibid., h. 72

${ }^{27}$ Lihat Himpunan Putusan Majelis Tarjih Muhammadiyah, (Yogyakarta: Pimpinan Pusat Muhammadiyah, t.th), cet ke-3, h. 304-306

${ }^{28}$ Ibid.

${ }^{29}$ Lihat Muhammad Najetullah Siddiqi, "Issues in Islamic Banking: Selected Papers" dalam Islamic Economic Series-4, (Nairobi: Islamic Foundation, 1993), h. 9

${ }^{30}$ Ibid. 
bank Islam mengalami perkembangan yang cukup signifikan pada awal tahun 1970-an ${ }^{31}$. Namun demikian, sebenarnya para ahli banyak yang sepakat, sebagaimana dikutip dari $\mathrm{M}$. Syafi'i Anwar, ide bank Islam merupakan fenomena tahun 1960-an, meskipun pada dasarnya gagasan itu sudah terbaca sejak awal tahun $1940-\mathrm{an}^{32}$. Namun pada dekade ini kondisi tidak memungkinkan untuk merealisasikan pendirian bank-bank Islam. Dari hasil analisis tersebut dapat diketahui bahwa pada prinsipnya perbankan islam tidak dibenarkan adanya bunga bank yang secara substansial merupakan riba yang diharamkan dalam ajaran Islam.

\section{KESIMPULAN}

Berdasarkan pembahasan yang telah diuraikan dalam bab-bab sebelumnya dapatlah ditarik kesimpulan sebagai berikut :

1. Bahwa etika, Nilai dan prinsip perbankan syariah dalam sistem hukum ekonomi Islam adalah suatu kesatuan yang utuh dan tak terpisahkan. Keduanya saling mengikat tidak terpisahkan dan menjadi acuan dalam melaksanakan amal usaha (muamalah) sehingga semua aktivitas dalam ekonomi Islam selalu sesuai dengan ajaran islam dan terhindar dari pelanggaran terhadap nilai dan norma islam.

2. Bahwa etika, nilai dan prinsip perbankan syariah yang dinormakan dalam hukum ekonomi islam dimaksudkan adalah suatu konsep yang ditawarkan kepada umat manusia yang bersumber dari al-Qur'an dan Sunnah dalam hal melakukan hubungan atau transaksi dengan orang lain, khususnya dalam bidang keuangan sebagai manisfestasi dari ajaran islam dalam bidang perbankan. Etika, Nilai dan prinsip menjadi acuan dalam merumuskan norma hukum yang mengatur hubungan hukum dalam bindag perbankan. Semuan transaksi transaksi keuangan dalam perbankan harus tunduk pada norma hukum islam dan setiap muslim perlu kehati-hatian dan tidak terjebak dan termasuk dalam sistem transaksi perbankan yang tidak halal (riba dan subhat) sehingga eksistensi perbankan Islam semakin kokoh tumbuh dan kuat demi kemaslahatan umat manusia.

\section{DAFTAR PUSTAKA}

Achsen, H.lggi. Investasi Syariah di Pasar Modal. Menggagas Konsep dan Praktek Manajement Potopfolio. Cet 1; Jakarta : Gramedia, 2000.

Ali, Muhammad Daud. Kedudukan Hukum Is1am da1am Sistem Hukum Indonesia. Cet. 1; Jakarta : Yayasan Obor, 1984.

al-Jurjani, Ali bin Muhammad al-Syarif. Kitab, al-Ta'Rifat (Beirut : Maktabah Libnan, 1990).

Antonio, Muhammad Syafi i. Bank Syariah dari Teori ke Praktek ( Jakarta Gema Insani Press, 2001).

${ }^{31}$ Lihat M. Syafi'i Anwar, "Alternatif Terhadap Sistem Bunga", dalam Ulumul Qur'an, (Jakarta: Lembaga Studi Agama dan Filsafat [LSAF]), Vol-II No. 9 tahun 1991 M/1411 H, h. 11.

${ }^{32}$ Ibid. 
Anwar, M. Syafi'i. “Alternatif Terhadap Sistem Bunga”, dalam Ulumul Qur`an, (Jakarta ; Lembaga Studi Agama dan Filsafat [LSAF]), vol-II No. 9 tahun $1991 \mathrm{M} / 1411 \mathrm{H}$.

Coulson, Noel J. Conflict and Tension in Islamic Jurisprudence, Chicago : The Univeersity of Chicago Press, 1969.

Departemen Agama RI, Al-Qur`an dan Terjemahannya. Semarang : CV . A1Waah, 1995.

Dewi, Gemala. Aspek Perbankan Perasuransian Syariah di Indonesia. Cet. 1; Jakarta: Kencana, 2004.

Djamil, Fathurrahman. Metode Ijtihad Majelis Muhammadiyah, (Yogyakarta : Pimpinan Pusat Muhammadiyah, t.th), cet ke-3.

Dawam Rahardjo, Muh. Islam dan Transformasi Sosial-Ekonomi, Lembaga Studi Agama dan Filsafat, Jakarta, 1999 h. 405

Hassan, A. Riba : Beberapa Pembahasan Masalah Riba (Bangil : Percetakan Persatuan, 1975. Dawam Rahardjo, "Ensiklopedi Riba".

Keraf, Sony. Etika Bisnis: Membangun Citra Bisnis sebagai Profesi Luhur (Yogyakarta : 1991).

Khalaf, Abdul Wahab. 'Ilm Usul al-Fiqh, Jakarta : Maktabah al-Da'wah al-Islamiyah Syabab al-Azhar, 1410/1990, cet. 8 .

Masyhuri, A. Azis. Masalah Keagamaan Hasil Muktamar dan Munas Ulama`Nahdatul Ulama, (Surabaya : Dinamika Press, 1997).

Mannan, Muhammad Abdul. Islamic Ekonomic : Theori and Practice, di terjemahkan oleh Potan Arif Harahap dengan judul : "Ekonomi Islam: teori dan praktek (Dasar-dasar Ekonomi Islam )". Cet. 1; Jakarta; Intermasa, 1992.

Moleon, J. Lexy, Metodologi Penelitian Kualitatif. Cet. Xl ; Bandung : Remaja Dosmakarya, 2000.

Nugroho, Alois A. Dari Etika Bisnis ke Etika Ekobisnis (Jakarta : Grasindo, 2001 M.).

Poerwordaminto, W.J.S. Kamus Umam Bahasa Indonesia (Jakarta : Balai Pustaka,1993 M.)

Prawiranegara, Syafruddin. Ekonomi dan Keuangan : Makna Ekonomi Islam (Kumpulan Karangan Terpilih jilid II), (Jakarta: CV Masaagung, 1988).

Rahardjo, M. Dawan. Etika Ekonomi dan Manajemen (Yogyakarta : Tiara Wacana yogya, 1990).

Saeed, Abdullah. Islamic Banking and Interest A Study of Prohibitiaon of Riba and its Contemporary Interpretatio, (Leiden EJ.Brill, 1996).

Siddigi, Muhammad Najetullah. "Issues in Islamic Banking : Selected Papers" dalam Islamic Economic Series-4, (Nairobi : Islamic Foundation, 1993).

Sukardja, Ahmad. "Riba, Bunga Bank dan Kredit Perumahan" dalam Huzaimah T. Yanggo dan Hafiz Anshary AZ, Problematik Hukum Islam Kontemporer, (Jakarta : LSIK, 1995) Buku III. 
Suma, Muhammad Amin. Himpunan Undang-undang Perdata Is1am dan Peraturan Pelaksanaannya 1ainnya di Negara Hukum Indonesia. Cet. 1; Jakarta : Raja Grafindo Persada, 2004.

Sumitro Warkum, Asas-Asas Perbankan Islam dan Lembaga Terkait (Bamui dan Takaful) di Indonesia, (Jakarta z; Raja Grafindo Persada, 1997).

Tim Redaksi, Ensiklopedi Hukum Islam, PT. Ichtiar Baru, Van Hoeve, Jakarta, th. 